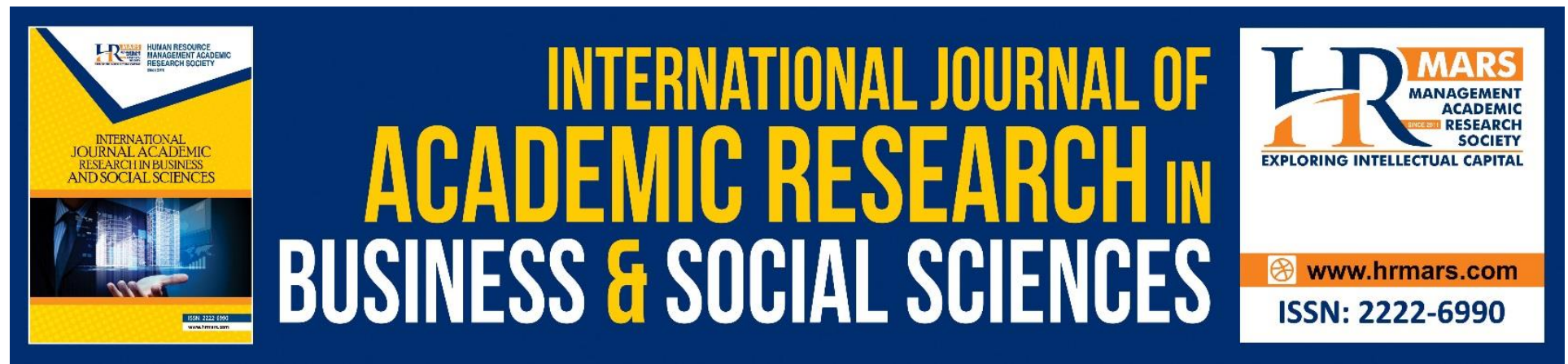

\title{
Structural Productivity Convergrence of Rcep
}

\section{A.M Dyg Afffizzah, Awgku Alizra A.A, Ting Mee Sing}

To Link this Article: http://dx.doi.org/10.6007/IJARBSS/v10-i9/7990

DOI:10.6007/IJARBSS/v10-i9/7990

Received: 24 July 2020, Revised: 19 August 2020, Accepted: 08 September 2020

Published Online: 27 September 2020

In-Text Citation: (Afffizzah, Alizra, \& Sing, 2020)

To Cite this Article: Afffizzah, A. M. D., Alizra, A. A. A., \& Sing, T. M. (2020). Structural Productivity Convergrence of Rcep. International Journal of Academic Research in Business and Social Sciences. 10(9), 1111-1125.

\section{Copyright: (C) 2020 The Author(s)}

Published by Human Resource Management Academic Research Society (www.hrmars.com)

This article is published under the Creative Commons Attribution (CC BY 4.0) license. Anyone may reproduce, distribute, translate and create derivative works of this article (for both commercial and non-commercial purposes), subject to full attribution to the original publication and authors. The full terms of this license may be seen

at: http://creativecommons.org/licences/by/4.0/legalcode

Vol. 10, No. 9, 2020, Pg. 1111 - 1125

http://hrmars.com/index.php/pages/detail/IJARBSS

JOURNAL HOMEPAGE

Full Terms \& Conditions of access and use can be found at http://hrmars.com/index.php/pages/detail/publication-ethics 


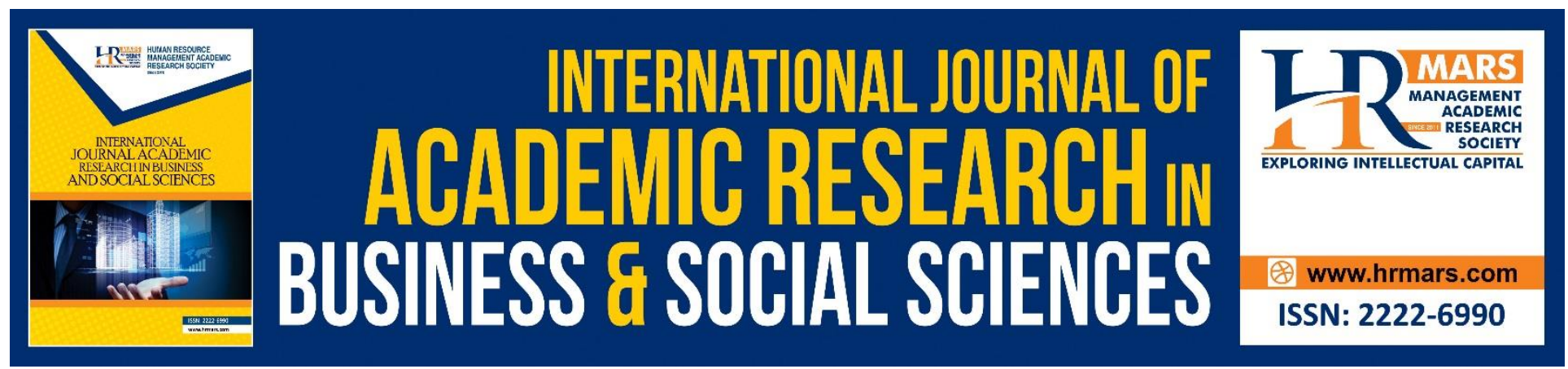

\title{
Structural Productivity Convergrence of Rcep
}

\author{
A.M Dyg Afffizzah, Awgku Alizra A.A, Ting Mee Sing \\ Faculty of Economics and Business, Universiti Malaysia Sarawak, 94300, Kota Samarahan, \\ Sarawak, Malaysia.
}

\begin{abstract}
This study aimed is to test the convergence on value added share of four major sectors namely manufacturing, services, agriculture and construction within a group of selected Regional Comprehensive Economic Partnership (RCEP) referring to Malaysia, Brunei Darussalam, Singapore, Thailand, Indonesia, Philippines, Japan, South Korea, China, India, Australia and New Zealand. From the finding it shows that there is no panel structural convergence found in all four sectors for all the countries. However, it does not indicate that there is no possibility of convergence because a country might cluster with another country. Among the four major sectors, agricultural sector shows the most diverse formation of convergence indicating vast gap in its agricultural sector development among the RCEP countries. Yet manufacturing sectors shows more similarities and common characters shared by countries in the study. In other words, RCEP countries are more similar in its development in term of its manufacturing performance. Structural convergence is indeed essential to strengthen the integration of economics in order to achieve the objective of RCEP Based on the results, a country ought to build regional linkages with another country as well as examine their own similarities with other regions. When the countries happen to share similar structural economy, any form of external shocks will result in symmetric but depending on the areas.
\end{abstract}

Keyword: Convergence, Club Convergence, RCEP Countries, Structural Productivity, Structural Convergence.

\section{Introduction}

Regional Comprehensive Economic Partnership (RCEP) is a framework formed in 2012 inspired by the AFTA with collaboration of the ASEAN countries. The negotiations within the RCEP is beneficial to make the ASEAN's economics must more recognized globally. The essential mission of RCEP is to transform ASEAN into a single market which most of the ASEAN economies are diverse. overview of the productivity growth, value added share and labour share of RCEP.

Petri, Plummer and Zhai (2014) mentioned that the RCEP is considering still at their earlier stage due to liberalization and diversity. The progression is low which makes the East Asia way too far from the European economic development. The economic performance of each country in RCEP are varies which experienced different level of growth. Take an example from Brunei Darussalam, this country is well known as high income group but still their productivity is considering low. 
Compared to South Korea or Japan, their income level is balance with their productivity (Global Competititvenes Report, 2003). Borsi and Metiu (2015) in their previous study investigated the economic convergence of 27 European Union countries by testing the real income per capita and found that no overall convergence occurred. However, real income per capita is not necessary a suitable indicator to robust the convergence test. In fact, A.M Dayang Affizzah (2011) also indicated that the income should be diverse in different micro perspectives to create a flexible framework. Therefore, this research aims to test the value added of the four major industries, namely manufacturing, services, agriculture as well as construction to define the structural convergence within the selected countries sectors in 12 selected RCEP countries able to converge with one another. Furthermore, the RCEP countries are performing in different paths of economic transition whereby various possibilities of convergence clubs which leads to long-run convergence relationship may exist as well.

\section{Structural Convergence}

Structural convergence refers to countries that share similarities in terms of economic structure associated with a convergence of income per capita. Thus, it is an important process to determine which countries belong to the same economic or catching up with among each other that may share similar pattern of transition path. The structural convergence is needed to form a monetary union in future. Therefore, by highlighting on the productivity of major industrial sector of each country in the RCEP, it will show similarities in converging process and enable us to determine countries that may catching up or diverge from the rest of the sample. Affizah (2011) et al states that income convergence does not necessarily imply structural convergence

Specifically, convergence is an essential tool to examine the union of the region's monetary by measured their level of value added. The productivity data identified will be useful to examine the robustness of the convergence. In fact, the regions productivity is differing from one country to another country depending on their population and GDP per capita. It is necessary for the ASEAN to not fully relies on the European Union (EU) as in Affizzah (2011) mentioned that the East Asian economies ought to form their own regional groupings. Hence, this research study intends to reduce the gap in the literature regarding this area of study particularly on convergence testing within the RCEP countries.

This study aimed to test the convergence on value added share of four major sectors namely manufacturing, services, agriculture and construction within a group of countries. Hence, the selected country referring to six ASEAN countries which is Malaysia, Brunei Darussalam, Singapore, Thailand, Indonesia, Philippines by excluded the Cambodia, Lao PDR, Myanmar and Vietnam. On the other hand, the ASEAN Free Trade Area (AFTA) countries that selected are Japan, South Korea, China, India, Australia and New Zealand.

\section{Literature Review}

The rising of global economy nowadays had affected the Asia which later creates low population growth and less convergence in future. Yet, Sonia etc (2017) found that the economic integration of South East Asia well said to accelerate regionally over time especially with the formation of RCEP. Therefore, it is crucial to create a steady monetary union and whether or not the selected 
ASEAN and its FTA countries able to determine the existence of the structural convergence within themselves.

A crucial empirical analysis by A.M Dayang Affizzah (2011) regarding structural convergence in JAKITH productivity states that there is no existing of structural convergence of value added in JAKITH. The study found that only labour share shows strong convergence magnitude. Despite that there is no aggregate convergence for the whole sample of JAKITH yet there is existence of club convergence, perhaps due to distinguished common path of manufacturing sector which results in different level of convergence.

Using log $t$ regression test, Hamit-Haggar (2013) studies the cluster of convergence of real GDP per capita, labour productivity, capital intensity and TFP growth in Canadian provinces between period of 1981 to 2008. Overall result found three club convergence in some of the provinces from both GDP per capita and labour productivity whilst divergent results in capital intensity and TFP growth but only on certain provinces. Hence, no single form of club convergence found in Canadian provinces.

Apergis, Panopoulou and Tsoumas (2010) aimed to study the real capita output convergence together with the transitional behaviour in 14 EU countries with period of 1980 to 2004. By employing production function growth accounting approach by Philips and Sul (2007), the finding shows that there is no homogenous convergence club in EU-14. At first place, the EU-14 had different technological conditions which sensitively control their own growth patterns and convergence behaviour. Furthermore, labour productivity become the dominant factor while integration ought to contribute to real convergence.

Differ from other studies, study by Nagayasu (2011) clarified that a group of countries that already in a monetary union experienced the same level of inflation. Hence, investigation of this hypothesis is conducted by testing the Japan's inflation to provide an evidence by using quarterly data of 1975Q1 to 2005Q4 within 10 districts. Thus, there is clear evidence that the regions in Japan has different regional inflation. However, in his study found that price convergence does not exists in a group of regions instead found small evidence regarding the convergence in some subgroups.

Rodrik (2012) mentioned that the manufacturing industries contributed strong evidence on unconditional convergence particularly in labour productivity. Thus, in his previous study intend to prove the facts by studying the sample data from 118 countries to identify the robustness of the unconditional convergence. It is clear that there is strong convergence occurred from manufacturing although the aggregate convergence failed to show due to certain low-income countries involved in the test.

Different from the researchers discussed above, Miketa and Mulder (2005) identified the trend of growth and convergence by measuring the energy productivity in developed and developing countries. Specifically, this study only focused on energy productivity in 10 manufacturing sectors between the period of 1971 to 1995 . They found that the cross-country is difference in absolute 
energy productivity declined except for non-ferrous metals sectors. The hypothesis testing is challenged and prove that there is catch-up process in manufacturing sectors and therefore convergence is found in different steady states although some of the countries failed to catchup.

\section{Methodology}

According to Islam (2003), there are many different definitions and methodologies can be used in the process of testing the convergence research. However, in order to examine the existing of the structural convergence in value added share of RCEP, Philips and Sul (2007) new methodology will be use because more flexible. To ensure the positive evidence occurs, the panel dataset of this study only based on the selected countries which called Australia, China, India, Japan, Korea, New Zealand, Brunei Darussalam, Indonesia, Malaysia, Philippines, Singapore and Thailand for the period of 2000 to 2018.

Nevertheless, the measurement of the structural convergence also will be based on the regions' value added share of four major sectors included (manufacturing, agriculture, services, and construction) aim to discover as whether the ASEAN+6FTA is the right candidates for RCEP to form a monetary union.

\section{The Nonlinear Dynamic Factor Model}

The nonlinear factor model used in this study represents the panel data model by combining the time series data and cross-section. Hence, the panel data model for log per capita real income or likely called neoclassical growth model under heterogeneous technological progress with the transformed equation shows the separating common from idiosyncratic components:

$$
\log y_{i t}=\left(\frac{a_{i t}+x_{i t} t}{\mu_{t}}\right) \mu_{t}=\delta_{i t} \mu_{t}
$$

Based on (1), $\delta_{i t}$ and $\mu_{t}$ are time-varying components which represents as idiosyncratic and common elements respectively. $\delta_{i t}$ is a distance measurement between $\mu_{t}$ and $X_{i t}$ or likely how the individual economic performance relates over time to $\mu$. Where $\mu_{t}$, a growth component that for example acts as a proxy for common components across individuals. On the other hand, below shows the actual transitional path for log per capita model:

$$
\log y_{i t}=\log A_{i 0}+\log \tilde{y}_{i}^{*}+\left(\log \tilde{y}_{i 0}-\log \tilde{y}_{i}^{*}\right) e^{-\beta_{i t}}+x_{i t} t=a_{i t}+x_{i t} t
$$

It summarized the relationship in terms $a_{i t}$ as $t \rightarrow \infty$ with $\log A_{i t}$ as the log of technology accumulation for economy $i$ at time $t$. Where $\tilde{y}_{i 0}$ is the initial log per real capita income and $\log \tilde{y}_{i}^{*}$ is the steady state level. In addition, $\beta_{i t}$ is the time-varying speed convergence rate and generally rich nation with high level of technological accumulation or high education begin with high $\beta_{i t}$ and the speed of convergence started to accelerate. Conversely, the poor countries with low level of technological accumulation, there is low of $\beta_{i t}$ at the beginning and correspondingly slow speed of convergence. In fact, the transition of $x_{i t}$, the growth rate is homogenous with $\beta_{i t}$ and presumed to have some elements that are common across economies. 


\section{The Log t Test}

On the other hand, the common factor of $\mu_{t}$ will be remove by scaling to ease the estimation of the time varying elements of $\delta_{i t}$ and measures the transition elements for economy $i$ relative to the cross-section average. Therefore, below shows the relative transition of the coefficients $\delta_{i t}$ :

$$
h_{i t}=\frac{X_{i t}}{N^{-1} \sum_{i=1}^{N} X_{i t}}=\frac{\delta_{i t}}{N^{-1} \sum_{i=1}^{N} \delta_{i t}}
$$

Where $h_{i t}$ called as the 'relative transition path' or unity which traces out an individual trajectory for each $i$ relative to the average in short run.

On the other hand, if the panel units converge and all the factor loading $\delta_{i t}$ approach to a fixed $\delta$, the relative transition path, $h_{i t}$ converges to unity and the cross-sectional variation, $H_{t}$ as follows:

$$
H_{t}=N^{-1} \sum_{i=1}^{N}\left(h_{i t}-1\right)^{2}
$$

When ultimate convergence occurred which there is limitation of $h_{i t} \rightarrow 1$ and hereby, the mean square transition differential which provides a quadratic distance measure for panel from common limit. There are various possibilities might occur for example $H_{t}$ may converge to a non-zero constant or not converge to bounded zero and maybe diverge. However, when there is a form of club convergence, $H_{t}$ basically converges to zero and remain positive. A semiparametric model, (5) for the transition coefficients that allows for heterogeneity over time and across individuals is presented below:

$$
\delta_{i t}=\delta_{i}+\frac{\sigma_{i} \xi_{i t}}{L(t) t^{\alpha}}, L(t) \rightarrow \infty \text { as } t \rightarrow \infty
$$

Where $\delta_{i t}$ is fixed, $\sigma_{i}$ is idiosyncratic scale, a random variables of $\xi_{i t}$ is i.i.d. $(0,1)$ across $i$ but may be weakly dependent over $t$ and $L(t)$ is a slowly varying function with $\alpha$ as a parameter governs the rate at which the cross-section variation over the transition decays to zero over time. Hence, this formulation ought ensure $\delta_{i t}$ converges to $\delta_{i}$ even when $\alpha=0$ or even the convergence performance in slow rate.

With hypothesis testing of convergence written as follow:

$H_{0}: \delta_{i}=\delta, \alpha \geq 0$ (There is convergence between the countries)

$H_{A}: \delta_{i} \neq \delta, \alpha<0$ (There is no convergence between the countries) 
Figure 2: Algorithm Cluster and Club Convergence Club Proced

- Listed each of the country according to their last observation value of value added share.

- The highest country in rank will be selected as base and formed a new subgroup of size $k$. The $\log t$ regression test will be run and computed the convergence test

- Add one country at a time from the remaining members and perform log $t$ test. Add up the country only if the t-statistic is greater than the critical value of -1.65 at 5 per cent significant level meaning that there is an evidence of convergence club.

- If the t-statistic is less than the critical value of -1.65 , meaning divergence and no adding country. Instead, form a new subgroup and repeat the process of $\log t$ test.

The rejection rule for both panel and club convergence is if the t-statistic is smaller than the critical value, -1.65 , the null hypothesis will be rejected. On time series data in which the first $r$ per cent of the data is will be ignored for any empirical log $t$ regression test (Philips and Sul, 2007a). Therefore, Philips and Sul (2007a) suggested that the data will be trim by setting apart of $r=0.3$ of the sample data. Hence, the sample period required is from 2005 to 2017 which means discarded five years of sample in this study.

\section{Empirical Results}

Full Panel Convergence

Table 4: Results of Panel Convergence

\begin{tabular}{ccc}
\hline Sectors & $\widehat{\boldsymbol{b}}$ & Remarks \\
\hline Manufacturing & -70.27173 & Divergence \\
Services & -204.6041 & Divergence \\
Agriculture & -220.0188 & Divergence \\
Construction & -45.37648 & Divergence \\
\hline
\end{tabular}

Table 1 shows the overall results for panel convergence in four sectors of 12 selected RCEP countries by using log $t$ convergence test. Analysing the full panel convergence of all the countries is essential to simply clarify their similarity. For the manufacturing sectors, result shows it is divergence with $t_{b=-45.04578}$ which is smaller than critical value of -1.65 . Hence, the null hypothesis is rejected for for 12 selected RCEP countries.

Similar evidence of other sectors namely services, agriculture and construction where the result also shows divergent. In facts that, this study containing both developed and developing countries which differ in economic development and level of income. Hence, all the four major sectors divergent in panel convergence which means the studies proceed to determine the 
existence of club convergence. Therefore, it is crucial to test the convergence at sectoral level in depth to prove that at certain point they still have probability to form a club convergence since they can converge at different equilibrium. Overall, at panel convergence, agriculture shows the highest value of $t$-statistic which indicates very slow catching up process followed by services, manufacturing and lastly construction.

The results of panel convergence were divergent in all sectors. However, it does not indicate that there is no possibility of convergence because a country might cluster with another country as can be seen in the figures above. In descending order, both manufacturing and services sectors formed five cluster convergence meanwhile for construction and agriculture are 3 and 1 respectively.

\section{Club Convergence}

Club Convergence in Manufacturing Sector

Figure 1: Illustration for Club Convergence in Manufacturing Sector

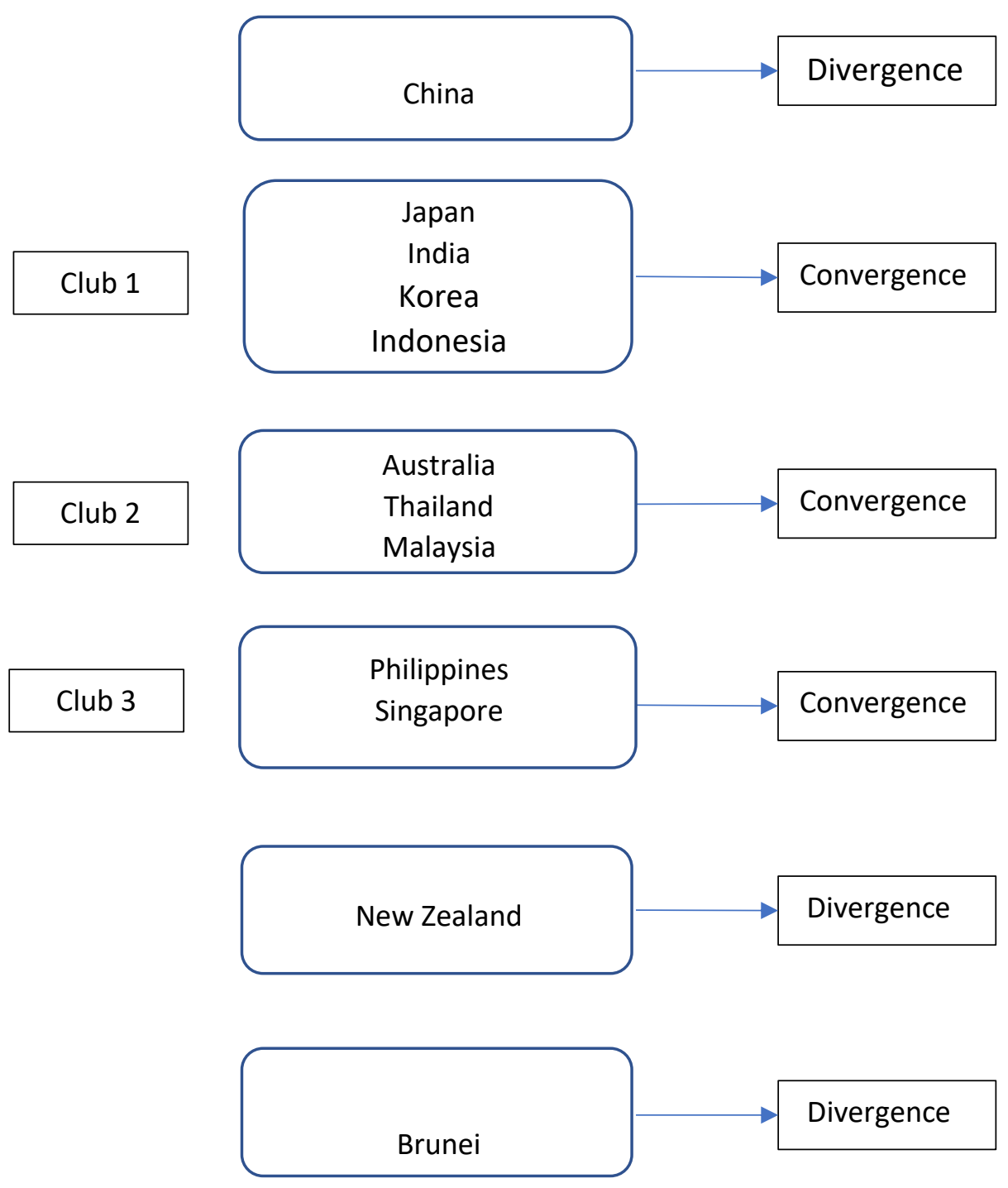


Based on the Figure 1, Indonesia and Korea shows interesting results and able to converge with Japan and India which had high manufacturing output for many decades. Growth of manufacturing in Indonesia and Korea was very crucial to increase their economic development. The consumer had high purchasing power and the industry eventually had high competitiveness. Surprisingly for Indonesia, the government highly encourage investment on manufacturing industry after being threatened of low quality in local human resources. Indonesia's biggest manufacturing industry is foods and beverage which exported to the worldwide. Meanwhile shipbuilders and smart phone industry had driven Korea into rapid economic development despite having highly skilled workforce and advanced technology.

Australia, Thailand and Malaysia formed the second club. Clearly, manufacturing sector played an important role to boost Malaysia's economic industry as Malaysia had the highest tstatistic value in this sector which is 9.751134. As compared Malaysia's industry to Australia, Australia recently seemed to focus on imported manufacturer goods to support their needs. Meanwhile in Thailand, they roughly more into strengthen the existing industry despite having high competitive investment but recently suffering from domestic economy which decreases their export demand due to high competition from regional areas like Malaysia and Philippines. As the last convergence club is membered by both Philippines and Singapore. Their vision on this industry is to increase global competitiveness by building strong linkages with other regions and shifts the industry into high value-added activities. 
INTERNATIONAL JOURNAL OF ACADEMIC RESEARCH IN BUSINESS AND SOCIAL SCIENCES

Vol. 10, No. 9, 2020, E-ISSN: 2222-6990 @ 2020 HRMARS

\section{Club Convergence in Service Sector}

Figure 2: Illustration for Club Convergence in Service Sector

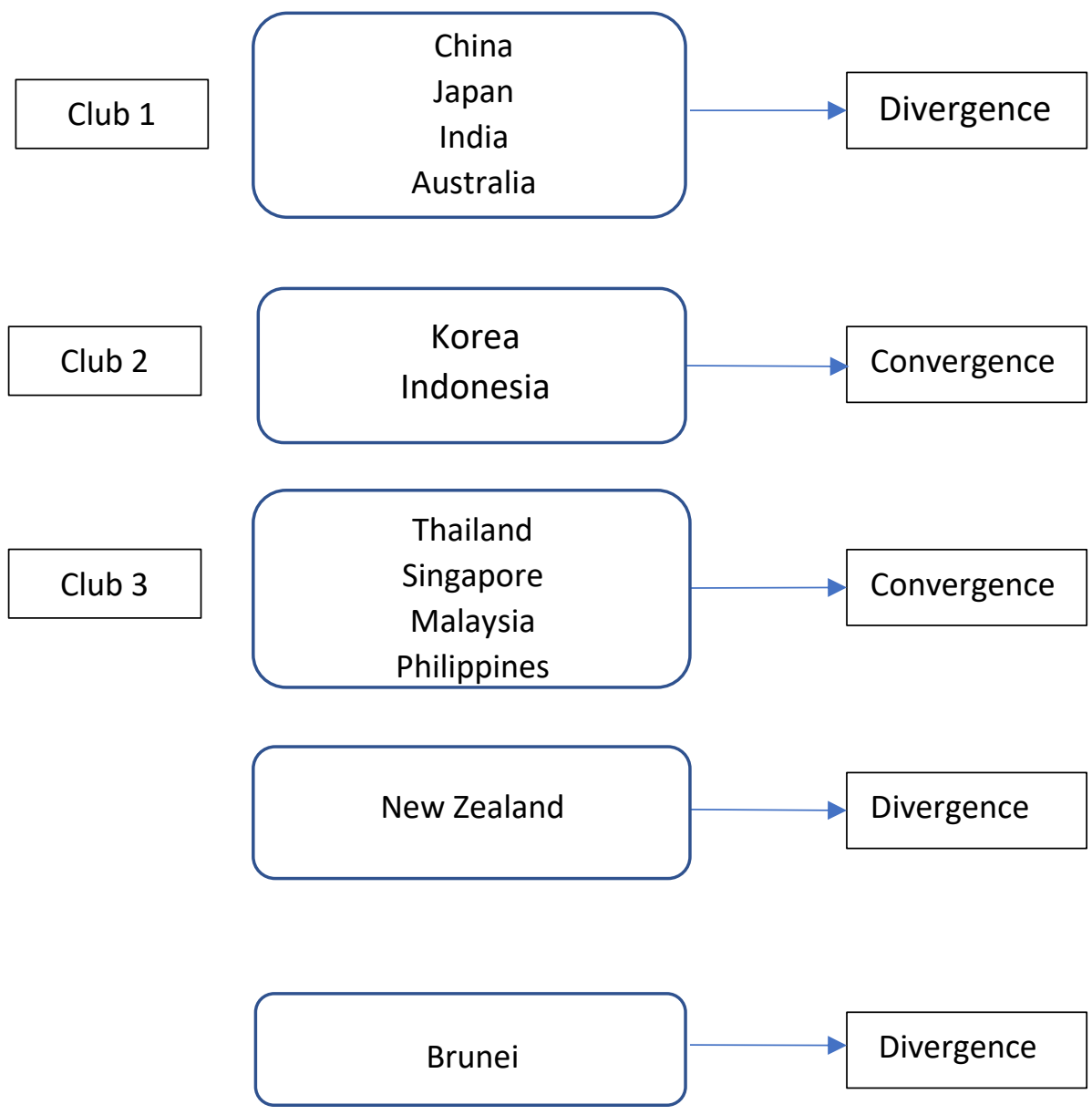

Moving to service sector, there is also three convergences formed based on the results in Figure 2. Again, New Zealand and Brunei diverged in this sector as well as in manufacturing. The value-added shares of Brunei is extremely low compared with the other regions whilst New Zealand slightly decrease after cluster with Malaysia and Philippines.

The very first club formed in service sector is between four core group which is China, Japan, India and Australia. India shows the highest t-statistic value with 9.27118 and significant at 5 per cent level. Correlated with manufacturing industry, services sector shall perform steadily based on how efficient the manufacturing is. Better access in services sector lead to increment in other industry. Decrement in Japan's services sectors makes China the first country to catch up followed by India and Australia. Japan is more into technology whereby relied on artificial intelligent involved in the industry which lead to poor services sectors. China, India and Australia on the other hand excessively promoting their services sector together with increment in other manufacturing, agriculture and construction. Second convergence club consists of Indonesia and Korea while the last groups are Thailand, Singapore, Malaysia and Malaysia. Those four countries are all Asian countries. Typical sources of growth in Asian countries are more on services sector. Hence, it is possible for these countries to form a club convergence. 
INTERNATIONAL JOURNAL OF ACADEMIC RESEARCH IN BUSINESS AND SOCIAL SCIENCES Vol. 10, No. 9, 2020, E-ISSN: 2222-6990 @ 2020 HRMARS

\section{Club Convergence in Agriculture Sector}

Figure 3: Illustration for Club Convergence in Agriculture Sector

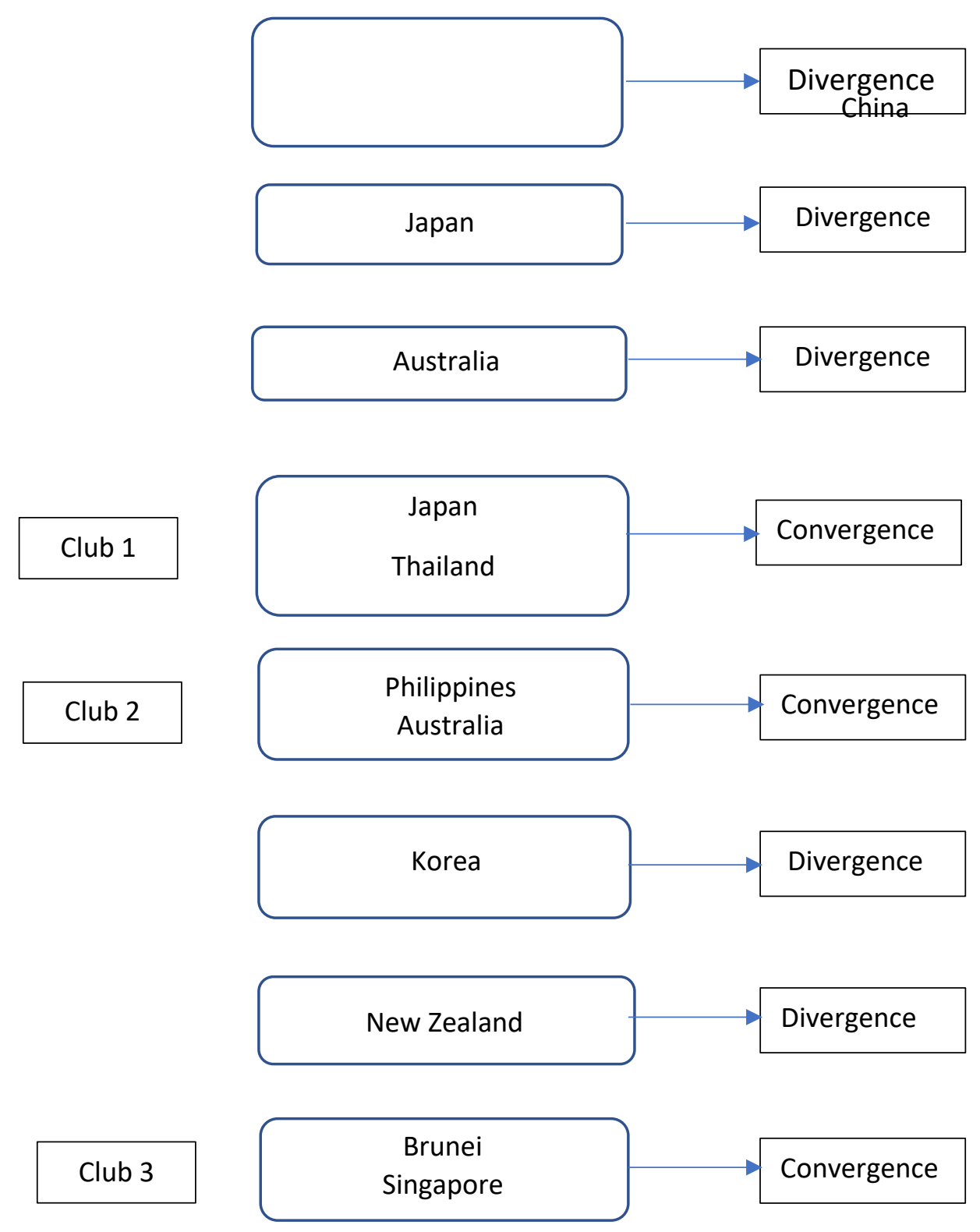


Agricultiral sector is the most diversified sectors with vast distinguish performance between the countries. There are three clubs can be found in the agricultural sector but most of the countries was diverged. Overall divergent countries are China, India, Indonesia, Korea and New Zealand, with high population density as most common silimarities among these countries. Generally, the value-added share of China, India and Indonesia keeps on increasing. China itself has a high demand on their agriculture for domestic consumption as well as for world export by as much as 20 per cent of consumption of the worldwide population.

The first club which is the core group with at most three countries consisting of Japan, Thailand and Malaysia. These countries emphasized on rice plantation as well as become rice exporters. In facts that, they almost shared the same value of value-added shares in 2016 which contributed 12 per cent to national income. Another club formed are Philippines converge with Australia. In 2011, Australia and Philippines had discussed on agriculture trade and cooperation. Both countries shared same interest in agricultural exporter which their value-added share almost the same despite increased prosperity among themselves. They strongly committed supported each other in term of climate change that might affect their agriculture industry, market access and food security.

Last but not least, Brunei converge with Singapore. Out of four sectors, Brunei only converged in agriculture sector. Lack of land for plantation and agricultural purposes, limit their expansion in the sector even for domestic consumption. Besides, there was less manpower on this industry as well and people interested more on public sectors due to high payment. However, both of this country known as high income country and seems like they shared the same economy behaviour. 
INTERNATIONAL JOURNAL OF ACADEMIC RESEARCH IN BUSINESS AND SOCIAL SCIENCES Vol. 10, No. 9, 2020, E-ISSN: 2222-6990 @ 2020 HRMARS

\section{Club Convergence in Construction Sector}

Figure 4: Illustration for Club Convergence in Construction Sector

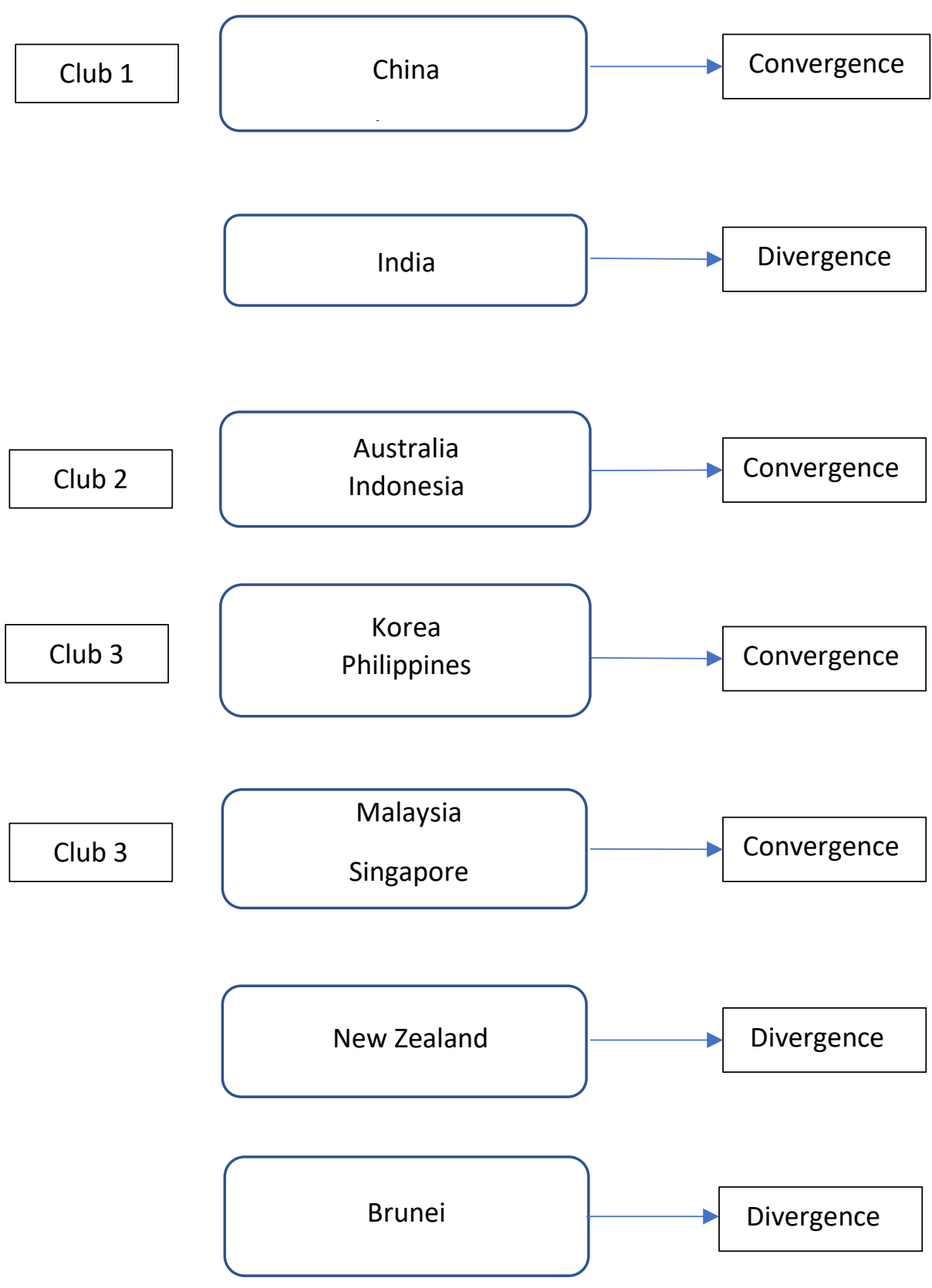


INTERNATIONAL JOURNAL OF ACADEMIC RESEARCH IN BUSINESS AND SOCIAL SCIENCES Vol. 10, No. 9, 2020, E-ISSN: 2222-6990 @ 2020 HRMARS

Construction formed the most number of club convergence as can be seen in Figure 10 which are four clustering groups with three countries divergent which is India, New Zealand and Brunei. Massive investment on infrastructure was necessary for India to improve the economy as well as reduce the rate of unemployment. India's economy in fact keeps on growing that might surpassing China in certain period forward. New Zealand recently overhauled the system regarding exploited of migrant students and migrant makes them look like stateless in New Zealand. They sacrificed their assets but the government seems abused them. Brunei in the contrary is indeed low in construction in fact placed bottom on the transition path in Figure 6.

Both China and Japan' construction industry make significant contribution to their economic growth. Often invest on major projects contribute to high return despite used high technology on construction industry. Construction industry expanded through trust and continuously demands on private housing in China and Japan. Japan's technology and China's ability was questionable since they keep on improving their quality, well-managed in business and totally advanced from other country in RCEP.

On the other hand, Indonesia seemed catching fast with Australia. Indonesia's t-statistic, 3.719659 is the highest in this sector. Indonesia's construction industry is booming and improving over the years as well as Australia. Increased demands on housing and apartment lead to active economy like for example demand on workers and employer might as well increase wages. Indonesia's construction market is the fastest in Asian particularly State budget mostly spent on social need and basic infrastructure.

In addition, the third and fourth clubs convergence of construction is Korea and Philippines and between Malaysia, Singapore and Thailand respectively shared similarities. The combination of these country was mixed and diverse which consist of different level of income. For Korea and Singapore for example, both of this country is high-income countries whilst Malaysia and Thailand is upper-middle income who have the same goals to improve and maintain economic development by enhancing construction industry.

\section{Conclusion}

The study analysed convergence of sectoral productivity on four major sectors of 12 selected RCEP countries which is manufacturing, services, agriculture and construction. Convergence methodology introduced by Philips and Sul (2007a) used in this study was generally flexible and researcher able to understand the transitional of economic behaviour of the countries for the period of 2000-2016. Poorer countries likely create a club convergence with another country with low productivity level.

Findings show that there is no structural convergence found in each of the four sectors for all the countries. Structural convergence is indeed essential to strengthen the integration of economics in order to achieve the objective of RCEP. But instead, there is only exists of club convergence. Based on the results, a country ought to build regional linkages with another country as well as examine their own similarities with other regions. When the countries happen to share similar structural economy, any form of external shocks will result in symmetric but depending on the areas.

Among the four major sectors, construction sectors show the most club formation followed by other sectors formed three clubs each. Moreover, China still leading and do not converge in two sectors which are in manufacturing and agriculture. Brunei converged one time which is in agriculture while in the rest sector it was divergent. New Zealand, on the other hands do not converging at all. 
INTERNATIONAL JOURNAL OF ACADEMIC RESEARCH IN BUSINESS AND SOCIAL SCIENCES

Vol. 10, No. 9, 2020, E-ISSN: 2222-6990 (C) 2020 HRMARS

The finding earlier also found Indonesia shows significant results among the other Asian countries. Most of the Asian countries itself converging with one another in services sectors.

\section{Acknowledgement}

Corresponding Author

Associate Professor Dr. Dayang Affizzah Awang Marikan

Faculty of Economics and Business

Universiti Malaysia Sarawak

Email: amdaffizah@unimas.my

\section{References}

Affizzah, A. M. D. (2011). Empirical studies of convergence in income, productivity and competitiveness: The Experience of Asian Economies. University of Southampton, School of Social Sciences, PhD Thesis, 1-128

Apergis, N., Panopoulou, E., and Tsoumas, C. (2010), "Old Wine in a New Bottle: Growth Convergence Dynamics in the EU." The Atlantic Economic Journal, 38: 169-181.

Borsi, M., \& Metiu, N. (2015). The Evolution of Economic Convergence in the European Union. Empirical Economics.

Islam, N. (2003), What have We Learnt from the Convergence Debate? Journal of Economic Surveys, 17: 309-362.

Miketa, A., \& Mulder, P. (2005). Energy productivity across developed and developing countries in 10 manufacturing sectors: Patterns of growth and convergence. Energy Economics.

Nagayasu, J. (2011). Heterogeneity and Convergence of Regional Inflation (prices). Journal of Macroeconomics 33: 711-723

Petri, P.A. and Plummer, M.G. and Zhai, F. (2014) The TPP, China and the FTAAP: The Case for Convergence (2014). Tang, Guoqiang and Peter A. Petri, eds. New Directions in Asia-Pacific Economic Integration. Honolulu: East-West Center. 2014.

Phillips, P. C. B., \& Sul. D. (2007a). Transition modeling and econometric convergence tests. Econometrica 75: 1771- 1855.

Phillips, P. C. B., \& Sul. D. (2007b). Some empirics on economic growth under heterogeneous technology. Journal Macroeconomic 29: 455-469.

Porter, M. E., Schwab, K., and Sala-i-Martin, X. (2004). The Global Competitiveness Report 20032004. Oxford University Press, 2004.

Rodrik, D. (2012). Unconditional Convergence in Manufacturing. The Quarterly Journal of Economics.

Selvarajan, S. K., \& Rossazana, A. R. (2017). Economic Liberalization and Its Link to Convergence: Empirical Evidence from RCEP and TPPA Countries. International Journal of Business and Society, 18, 439. 